\title{
Why 'Sustainable Development' Is Often Neither: A Constructive Critique
}

\author{
Alexander Lautensach ${ }^{1, *}$ and Sabina Lautensach ${ }^{2}$ \\ ${ }^{1}$ School of Education, University of Northern British Columbia, 4837 Keith Ave. Terrace, B.C. V8G 1K7, Canada; \\ Tel.: +1 250615 3334; Fax: +1 250615 5478; E-Mail: alex.lautensach@unbc.ca \\ ${ }^{2}$ Human Security Institute, 1025 Farkvam Rd. Terrace, B.C. V8G 0E7, Canada \\ * Corresponding author
}

Submitted: 19 December 2012 | In revised form: 1 February 2013 | Accepted: 22 March 2013 |

Published: 10 May 2013

\begin{abstract}
Efforts and programs toward aiding sustainable development in less affluent countries are primarily driven by the moral imperative to relieve and to prevent suffering. This utilitarian principle has provided the moral basis for humanitarian intervention and development aid initiatives worldwide for the past decades. It takes a short term perspective which shapes the initiatives in characteristic ways. While most development aid programs succeed in their goals to relieve hunger and poverty in ad hoc situations, their success in the long term seems increasingly questionable, which throws doubt on the claims that such efforts qualify as sustainable development. This paper aims to test such shortfall and to find some explanations for it. We assessed the economic development in the world's ten least affluent countries by comparing their ecological footprints with their biocapacities. This ratio, and how it changes over time, indicates how sustainable the development of a country or region is, and whether it risks ecological overshoot. Our results confirm our earlier findings on South-East Asia, namely that poor countries tend to have the advantage of greater sustainability. We also examined the impact that the major development aid programs in those countries are likely to have on the ratio of footprint over capacity. Most development aid tends to increase that ratio, by boosting footprints without adequately increasing biocapacity. One conceptual explanation for this shortfall on sustainability lies in the Conventional Development Paradigm, an ideological construct that provides the rationales for most development aid programs. According to the literature, it rests on unjustified assumptions about economic growth and on the externalization of losses in natural capital. It also rests on a simplistic version of utilitarianism, usually summed up in the principle of 'the greatest good for the greatest number'. We suggest that a more realistic interpretation of sustainability necessitates a revision of that principle to 'the minimum acceptable amount of good for the greatest sustainable number'. Under that perspective, promoting the transition to sustainability becomes a sine qua non condition for any form of 'development'.
\end{abstract}

Keywords: conventional development paradigm; human security; overshoot; sustainable development; utilitarianism 


\section{Introduction}

Following the dominant convention in the literature, we define development as multidimensional innovation or growth that achieves positive outcomes for the quality of human lives and/or for human security. It can manifest in the areas of financial income, employment, distribution of wealth, education, political autonomy, basic needs for survival, health of populations and ecosystems, equality, selfesteem and dignity, and freedom [1]. The latter includes Sen's [2] standard of individual capability. Those areas cover people's social, biological, and economic environments and have been recognised as the main indicators contributing to the human development index [3] and human security index [4]. Sustainable development, then, includes any such innovation or growth that does not compromise the ability of future generations to develop along the same lines ([5], p. 2). This corresponds to the definition by the World Conservation Union (IUCN), "improving the quality of human life while living within the carrying capacity of supporting ecosystems" ([6], p. 6). Thus, sustainability is all about avoiding to transgress systemic limits.

The above listed areas in which development can manifest suggest directly some ethical reasons why affluent countries engage in international development aid: When the citizens of a poor country suffer deprivations in those areas, and their own government and communities are not in a position to alleviate their situation, international aid seems indicated for several moral reasons. One of those reasons, though rarely explicated, is self interest. Helping a country develop into a valuable trading partner and enabling that country to purchase goods and services from the donor country (so-called tied aid) are in the obvious national self interest of the donor. The Paris Declaration on Aid Effectiveness [7] paved the way for development aid to become untied, broadly coordinated among donors, and designed and implemented by the recipient countries. But oftentimes political and strategic considerations still dominate the allocation decisions [8].

Much more widely advertised is the utilitarian motivation, under which helping a sufficiently large group of people transcend a situation that caused them to suffer inordinate deprivations, at only minor sacrifice to the donor, provides the necessary and sufficient justification for aid. Likewise, deontological and virtuebased ethics recognise a duty to relieve suffering, often manifesting in the mission statements of charitable organisations both religious and secular. Arguments in support of that duty often invoke human rights and basic needs. In practice, such humanitarian motives tend to focus on situations where the deprivation is most easily quantified, as in cases where populations experience extreme poverty, unemployment, undereducation, poor health, or homelessness.
The basic and widely shared agreement underlying these ethical motives is that knowledge of human suffering implies a duty to actively help. Much less general agreement is found when it comes to choosing the most appropriate ways to help. Short term relief measures dominate in cases of natural disasters such as the 2010 Haiti earthquake which displaced about 2.3 million Haitians (almost one quarter of the total population) and killed or injured over half a million. The UN's relief program focuses on the restoration of the island's economy and public health [9].

Designed as immediate disaster relief, it largely ignores how the island's climate, soil conditions, environmental trends, and population dynamics constrain its long term prospects for development. Those issues are considered beyond the program's time horizon and beyond its goals of providing immediate relief. In other words, international disaster relief is seldom justified by arguments invoking sustainability, nor would many suggest that it needs to be. This sets it apart from international development aid where the absence of a long-term focus can raise considerable problems, as we will explain presently.

\section{Disaster Relief and Development Aid}

The short term humanitarian priorities in disaster relief often seem relatively straightforward, suggesting unequivocally not only the need for immediate action but also what choices of aid measures might be indicated. Yet, as soon as the time frame is extended to the medium and long term, those choices become more debatable. This is most evident in cases of famine relief. For example, Peter Singer [10] considers the relief of human suffering to be a paramount moral duty; he argued that a famine always demands immediate food aid from any who are reasonably able. Arguing on the same humanitarian and utilitarian grounds, Garret Hardin [11] comes to the opposite conclusion, that famine relief in the form of food donations would be the worst anybody could do to a poor country. Because it promotes population growth without addressing the reasons for the famine, it will only cause worse famines in years to come. Both Singer and Hardin agree that family planning and contraception programs must be included in any such relief program. Curiously, neither author engages with deontological or virtue-based rationales for aid, which emphasise the charitable act as a duty independent of consequentialist considerations.

The difference between the two positions lies of course in the time frame and the preferred balance between the strategies of short-term alleviation versus long-term prevention. As it turns out, Singer's view usually carries the day with many relief programs, except that family planning is seldom included as an integral part $[12,13]$. That omission again underscores 
the short term perspective taken by such programs. Yet the conflict between the two strategies points to an ethical dilemma. One wonders just how severe the suffering and misery must be before we ought to ignore potential long-term complications, or how disastrous the long-term consequences of the relief action must be to justify the withholding of aid.

In the case of disaster relief we see no room for justifiable compromise; its concerns lie by definition in the short term, amounting to moral blinkers. The challenge of finding appropriate compromises becomes much more pressing where it regards programs for development aid which pursue explicit aims that extend into the medium and long term future. We would expect such programs to be guided primarily by considerations of long term benefits which would logically include sustainability if the time horizon is not specified. Thus, as long as the goals of a development program are not delimited in time, that development is automatically governed by the constraints of sustainability. Conversely, a program or initiative that promotes evidently unsustainable end states should come with clear temporal demarcations and disclaimers abrogating any responsibility for consequences that might ensue beyond those dates. We base those expectations on the ideals of beneficence and veracity that inform the professional codes of conduct of development workers and academics. In this study we examined to what extent major development programs live up to those expectations.

\section{Method}

Among the many programs at the national and international levels that all share the label of sustainable development, international development aid tends to benefit from a supranational perspective and a grounding in scientific analyses of needs and potentials. Rather than attempting to gauge the successes of individual programs we chose to examine the cumulative and synergistic outcomes occurring in their most deserving recipients, the world's poorest developing countries. We selected our sample countries on the basis of their rankings on the Human Development Index [3] and the Human Security Index [4]. Countries that scored low on both indices not only receive rather a lot of development aid, in many cases they represent situations that render development fundamentally imperative on humanitarian grounds. Development in this case is hardly a whimsical option but the only defensible course of action. Yet, unlike disaster relief, these programs explicitly pursue long- term goals. The question is: what shape do their strategies take, stopgap or long term?

In order to maximise the chances of those development efforts to achieve their objectives we excluded from our sample of poorest countries any that showed a failed states index (FSI) greater than 100, which includes the top thirteen [14]. Failing states are unlikely to provide the minimum requirements of infrastructure and political stability for successful development. In other words, they need more than the average kind of development aid, ranging from peace keeping to broad social reform, often supported by armed intervention. Because of recent destabilising developments, Mali was omitted from the sample in the revised version of this paper.

A program for sustainable development based on a genuine long term perspective would seek either to ensure the sustainable flourishing of the economy and of human well-being, or to pave the way for a smooth transition towards more sustainable structures and practices. The extent to which a country operates sustainably can be estimated by comparing its citizens' average ecological footprint (reflecting its demand of resources and its ecological impact) with the amount of biocapacity available for each citizen (reflecting its resources and ecosystem services, also referred to as natural capital) [15-17]. Based on a previous report [18] we use the country's sustainability quotient or SQ-the ratio of per capita ecological footprint over its available per capita biocapacity. An SQ of less than 1 indicates sustainability while greater than one indicates ecological overshoot [19]. The data are summarised in Table 1.

To assess the development of the sample countries for its sustainability we identified a major development aid program for each country, verified that it explicitly named sustainable development among its aims, and examined its major strategies for their effects on the country's biocapacity factors (bioproductive area and bioproductivity) and on its ecological footprint drivers (population growth, consumption of goods and services per person, footprint intensity; [19], p. 41). The sum of those effects would cause its SQ to either rise or fall. The trend by which the SQ changes over time indicates how sustainable the development of a country or region is, and whether the risk of ecological overshoot is increasing or decreasing. Where possible we selected grant programs over loan programs as the former contribute to Third World debt which itself contributes significantly to unsustainable practices (such as the replacement of food crops with exportable cash crops). The findings are summarised in Table 2. 
Table 1. Eleven of the world's poorest countries are compared to the European Union and the world average in their extent of sustainability. Example: Each citizen of Eritrea uses the equivalent of 0.9 global hectares to sustain their livelihood; the country of Eritrea has 1.6 global hectares of bioproductive land to offer to each citizen; this results in an SQ of 0.563 , meaning that Eritreans live within the carrying capacity of their land. Sources: $[19,20]$.

\begin{tabular}{lrrrrr}
\hline Country & $\begin{array}{l}\text { Ecol FP } \\
\text { (gha per person) }\end{array}$ & $\begin{array}{l}\text { Biocapacity } \\
\text { (gha per person) }\end{array}$ & \multicolumn{2}{c}{$\begin{array}{l}\text { HDI ranking } \\
\text { Max }=187\end{array}$} & $\begin{array}{l}\text { HSI ranking } \\
\text { Max }=232\end{array}$ \\
\hline Burkina Faso & 1.3 & 1.3 & 1.0 & 181 & 210 \\
Burundi & 0.9 & 0.5 & 1.8 & 185 & 225 \\
Eritrea & 0.9 & 1.6 & 0.563 & 177 & 218 \\
Ethiopia & 1.1 & 0.7 & 1.571 & 174 & 221 \\
Guinea-Bissau & 1.0 & 3.2 & 0.31 & 176 & 208 \\
Liberia & 1.3 & 2.5 & 0.52 & 182 & 229 \\
Mozambique & 0.8 & 1.9 & 0.421 & 184 & 198 \\
Niger & 2.3 & 2.1 & 1.10 & 186 & 222 \\
Rwanda & 1.0 & 0.6 & 1.67 & 166 & 220 \\
Sierra Leone & 1.1 & 1.2 & 0.92 & 180 & 224 \\
Togo & 1.0 & 0.6 & 1.67 & 162 & 219 \\
European Union (27) & $2.7-8.3$ & $1.0-12.5$ & $0.494-6.023$ & $3-55$ & $2-71$ \\
& Eur. Av. 4.8 & Eur. Av. 2.2 & Eur. Av. 2.2 & & \\
World & 2.7 & 1.8 & 1.5 & $1-187$ & $1-232$ \\
\hline
\end{tabular}

\section{Finding: 'Sustainable Development' Is Often Neither}

Table 1 lists the state of sustainability in eleven of the world's poorest countries, compared to the EU and the world average. The distribution of SQ values shows six countries operating sustainably-i.e. drawing only on the interest from their natural capital. The other six have exceeded their sustainable limit and are drawing on both principal and interest. Yet only four of those SQ values match the world average, and none of them comes close to the kind of overshoot exemplified by the European average of 2.2 (2003) or the US value of 2.1 (2007) [20].

The data confirm our earlier findings on South-East Asian countries [18], as well as global surveys [20], namely that poor countries tend to have the advantage of greater sustainability except in cases of excessive population size. In those cases ecological overshoot occurs in spite of small per capita footprints because the biocapacity resources are shared among too large a population, resulting in rampant poverty, often aggravated by post-colonial legacies of inequitable power structures and mismanagement. Those examples (in our sample, Burundi, Rwanda and Togo, and to a lesser extent Ethiopia) show that the SQ says nothing about a country's level of development; it only indicates how sustainably it operates.

In contrast to those high SQ countries, many developing countries with smaller populations show considerable potential to achieve the transition to a sustainable economy, aided by the fact that their natural capital has not yet been greatly reduced [19].
In our sample, those would be Niger and Burkina Faso. Suitable development aid could provide crucial support at the right time to make that transition possible before further population growth removes it beyond the horizon.

The remaining countries in our sample (Eritrea, Guinea-Bissau, Liberia, Mozambique, and Sierra Leone) show SQ values below 1.0, indicating that they are conducting their affairs sustainably for the time being. This encouraging finding needs to be evaluated in the light of the abject poverty that abounds in all of them. This means that the state of sustainability represents only one of several necessary conditions for human security and well-being. Moreover, their low SQ does not necessarily indicate that these countries have more resources to offer those poor multitudes; more likely their excess productivity is exported abroad to support other countries' overshoot. Yet, low SQ also indicates a significant opportunity for development aid - the chance that with the right kind of support those countries could remain sustainable while still relieving their poverty. The question is: are they likely to receive such support?

This leads to the problem posed by the dynamics of the situation. The SQ values in Table 1 only provide snapshots in time; they say nothing about the directions in which those countries are developing. An indication about probable changes for each country is given by its major source of development aid. Table 2 lists one major donor program for each country in the sample, along with its stated goals and the resulting ramifications on footprints and biocapacities. The data suggest a slim chance for an affirmative answer to the question raised in the preceding paragraph. 


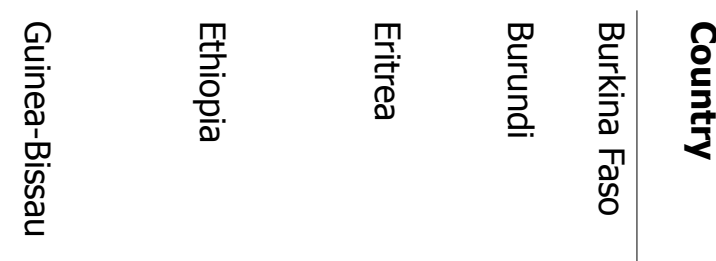

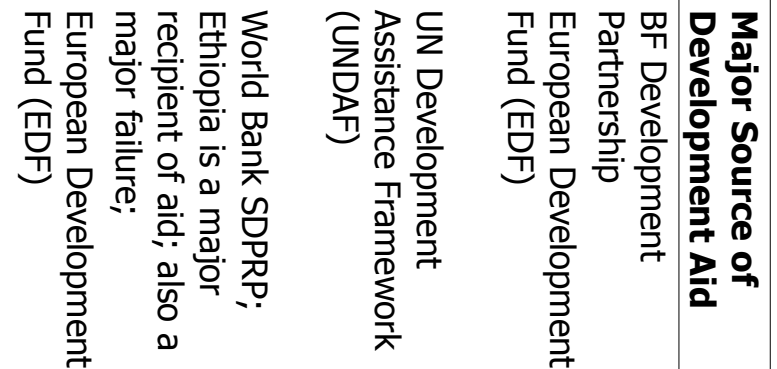

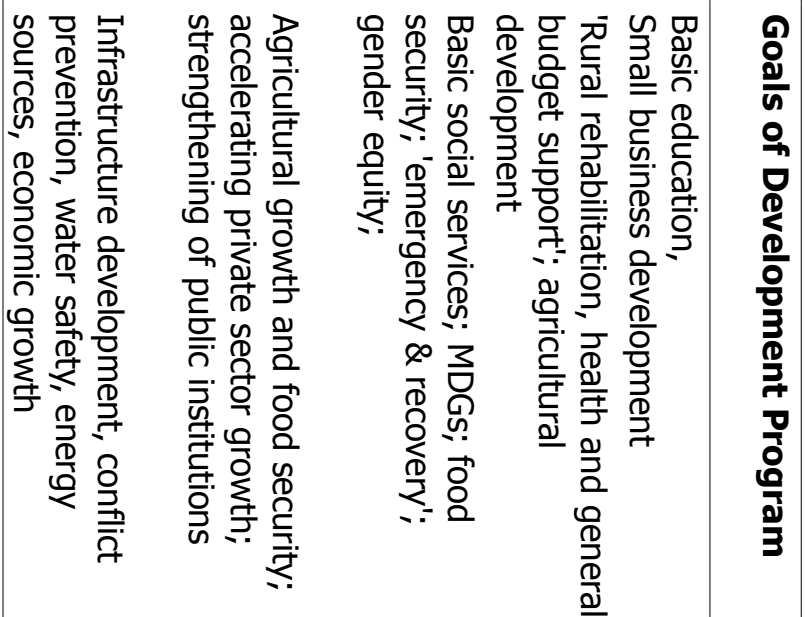

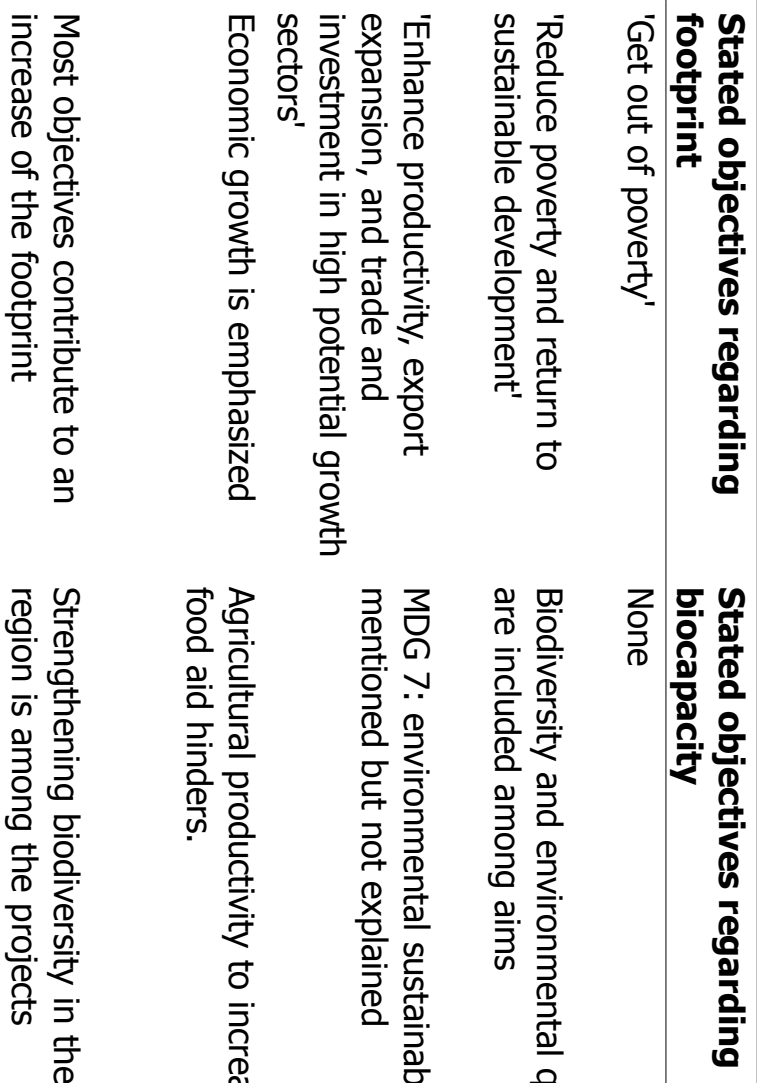

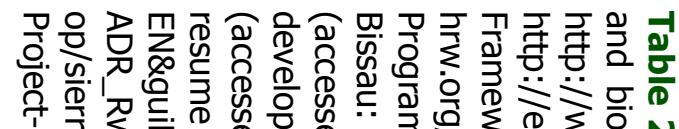

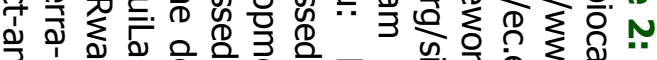

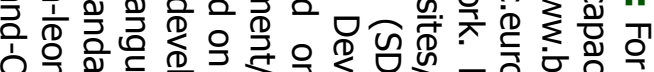

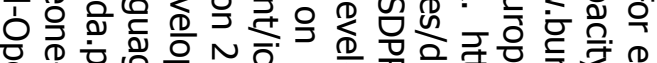

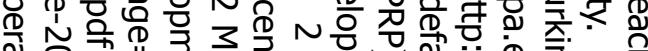

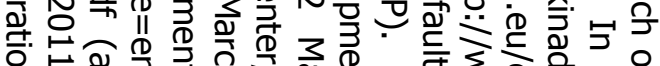

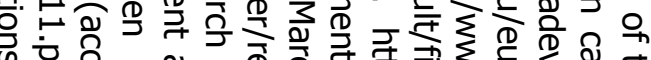

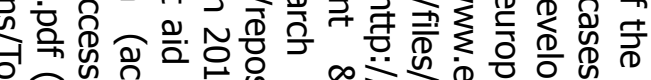

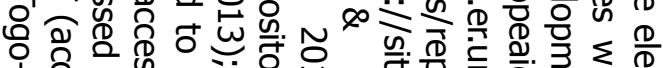

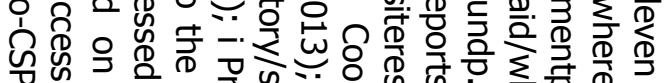

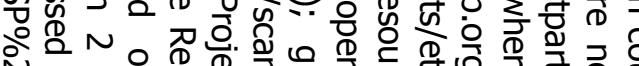

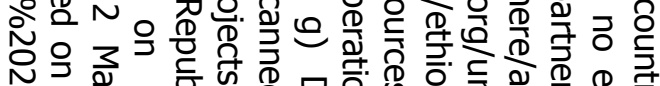

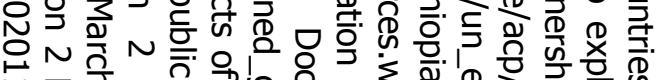

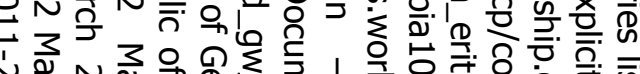

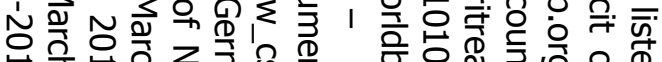

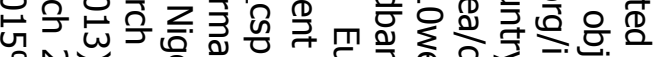
次 N

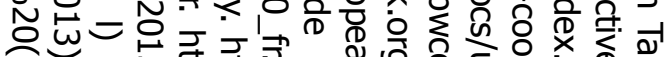

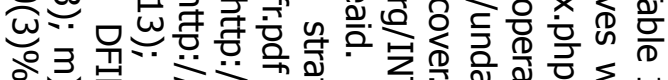

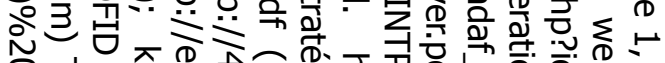

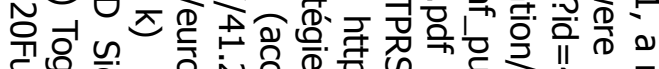

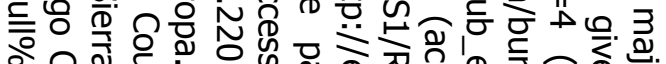

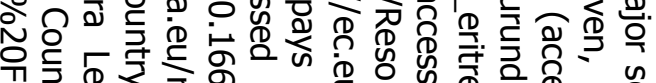

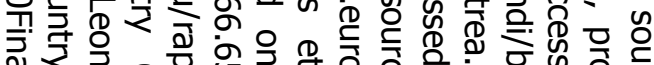

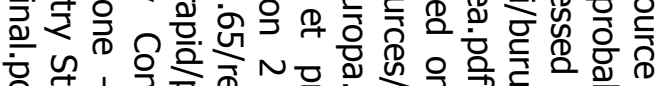

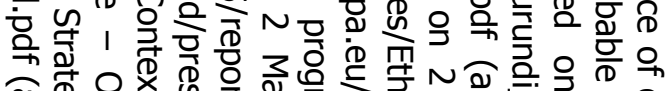

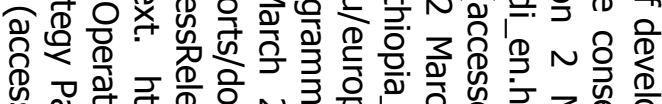

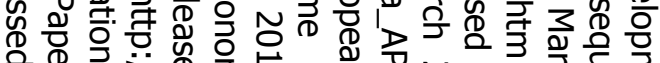

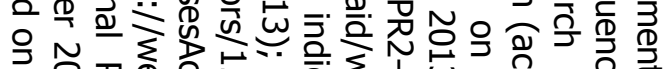
N

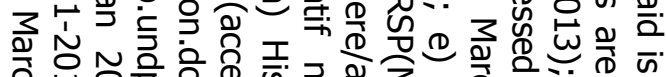

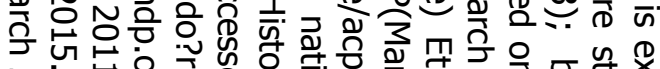

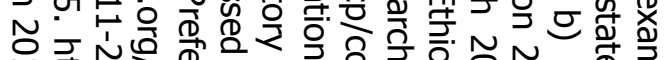
至垂

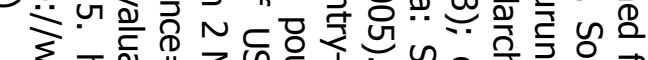

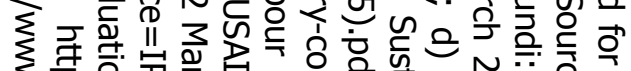

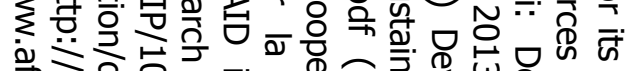
음 -

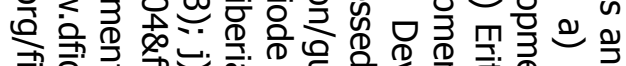

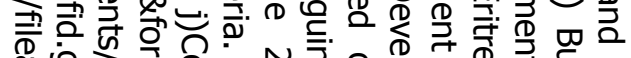

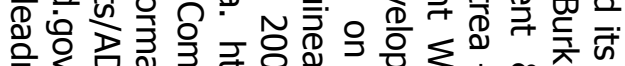

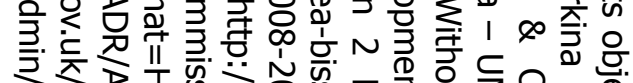

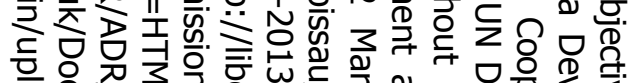

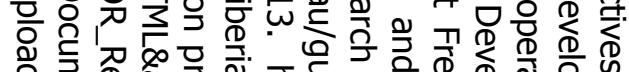

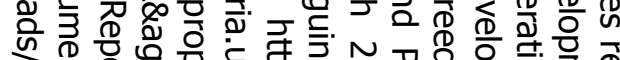

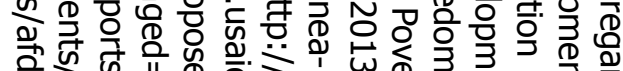

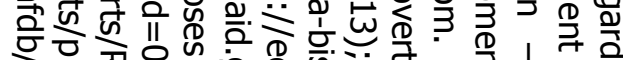

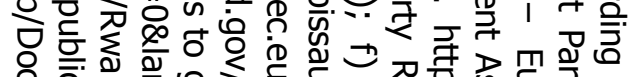

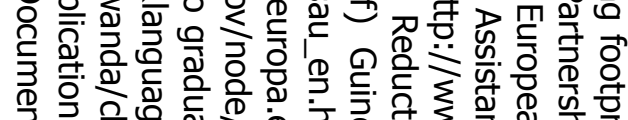

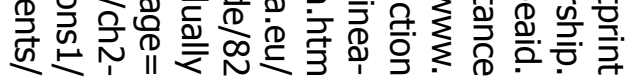




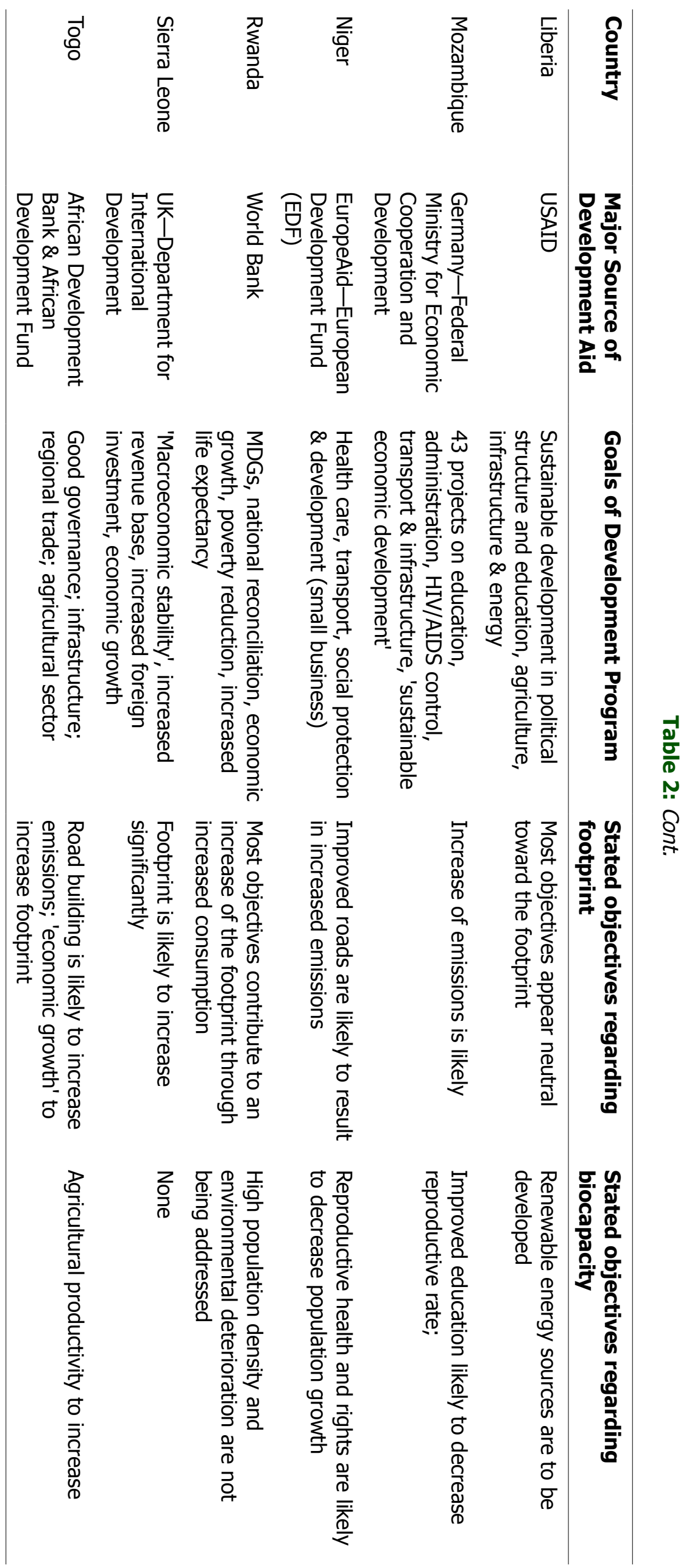


Even considering that each country receives aid from multiple other donors, the data indicate that these particular donors have not fully understood the challenge. Of even greater concern is the fact that if development aid tends to fail in the cases of those sustainable countries by not preventing them from slipping into overshoot, it is even less likely to succeed in the cases of unsustainable countries in helping them reduce it. This reinforces critiques that point to widespread failures of development aid in other areas besides sustainability [21].

The findings also raise the question about the possible impact that this development aid could have on the sample countries, in relation to their own domestic investments. For the countries with SQ values greater than 1.0, the total development aid received in 2011 ranges from $3.5 \%$ of GDP (Ethiopia) to $10.8 \%$ of GDP (Burundi) [22,23]. For the countries in the sustainable group those percentages range from 3.8 (Eritrea) to 8.1 (Sierra Leone), except for Liberia which received aid amounting to $35.9 \%$ of GDP. In the latter case certainly the specific development projects sponsored by the aid can be expected to exert a significant effect on the future state of sustainability status of the entire country. But even for the other countries in the sample the lower impact of aid does not mean that its effects will be negligible.

The main issue addressed by this paper, however, is not the projected impact of aid but to what extent aid projects labeled as sustainable development deserve that label. Having established that sustainability is hardly prevalent among the probable outcomes of the development programs in our sample, the question arises to what extent unsustainable development can or should qualify as development at all. Given our definition in the introductory paragraph, development that is not sustainable would reduce the ability of future generations to develop further in the same areas as are currently envisioned. A historical example for this situation is the early history of Cyprus where the resident population developed the island's abundant copper deposits by fuelling their smelters with the island's pine forests. Today Cyprus shows neither a viable copper industry nor any substantial pine forests [24].

Contemporary examples of unsustainable 'development' include the numerous incidences of regional ecological overshoot where populations demand more resources and services than their region can sustainably deliver. The inevitable consequence is that future generations will find their options reduced in terms of some or most of the ten areas of development we referred to earlier: financial income, employment opportunities, distribution of wealth, education, political autonomy, basic needs for survival, health of populations and ecosystems, equality, selfesteem and dignity, and freedom [25]. Fully half of our sample countries fall into that category. A well known global example is the explosive expansion of petroleum-based industries over the past century, bound to run its course within the next few decades and to be entered in history as the peak oil phenomenon [26-28]. While it lasted it brought unprecedented affluence and comfort to much of humanity; however, its negative long term consequences are likely to complicate the lives of many future generations. Whether peak oil should be regarded as development in the sense of our definition depends entirely on the observer's time frame. We must conclude that over the long term no development in the true sense will happen in those examples. Only over short terms can unsustainable practices qualify as development, if at all.

Ignoring the risk of tautology, authorities have invoked 'sustainable development' as a guiding concept at least since the Brundtland report [29]; certainly no administration would admit to its development policies as being unsustainable. But in order to avoid the tautology, development needs to be understood as any measure that furthers the transition to sustainability, to a more inclusive respect for grantable human rights (that includes future generations) [30], and a general commitment to the non-violent resolution of conflicts.

The stated goals of the programs listed in Table 2 generally emphasise poverty reduction through economic growth. Poverty provides the motive while economic growth is their remedy of choice. Thus these programs represent chimaeras of disaster relief and development aid, set on alleviating an objectionable situation without too much concern about the long term implications of continuing growth, or about any limiting variables that may create additional problems over the long term. This raises the question how so many well-paid, highly educated experts can persist in recommending such erroneous courses of action while any substantial progress towards sustainability continues to elude us.

\section{Why Is Sustainable Development So Rare?}

The finding that very few countries in our sample are moving towards sustainability according to this analysis (Burundi, Liberia, and possibly Mozambique appear to qualify) seems tragic though not entirely unexpected. Too many development program documents seem to promise everything to everybody, resembling election propaganda more than genuine plans towards the enduring welfare of humanity. The language of the UN document on indicators of sustainable development is devoid of any reference to limits [31]. Another example are the UN's Millennium Development Goals [32], listed in Table 3. Likewise, the Rio+20 United Nations Conference for Sustainable Development revealed a curious combination of multidisciplinary analysis and inattention to limits [33]. This widespread bias toward wishful thinking has ideological origins, which we will examine presently. 
Table 3. The Millennium Development Goals and Current Accomplishments ([32,35], adapted from [37]).

\begin{tabular}{ll}
\hline Goals & Current accomplishments \\
\hline Goal 1: Eradicate extreme poverty and hunger & $\begin{array}{l}\text { On track to reach below the target of } \\
23 \% \text { poverty rate } \\
\text { Some countries on track, others } \\
\text { behind }\end{array}$ \\
Goal 3: Promote gender equality and empower women & $\begin{array}{l}\text { Some progress in education, little in } \\
\text { employment and political } \\
\text { representation } \\
\text { Some regions on track, most } \\
\text { Goal 4: Reduce child mortality }\end{array}$ \\
Goal 5: Improve maternal health & $\begin{array}{l}\text { Largely behind } \\
\text { Largely behind on HIV and malaria, on } \\
\text { track for TB }\end{array}$ \\
Goal 6: Combat HIV/AIDS, malaria and other diseases & Far behind, despite vague definitions \\
Goal 7: Ensure environmental sustainability & $\begin{array}{l}\text { Mostly on track but definitions are } \\
\text { confusing and contradictory }\end{array}$ \\
Goal 8: Develop a Global Partnership for Development
\end{tabular}

Following Singer's view [10], the MDGs emphasise the eradication of poverty and disease as implicit moral duties. However, explicitly those goals are framed as fulfilling an entitlement, the right to enjoy 'freedom from want' [34]. As we elaborated elsewhere [25], the problem with such a right, while everyone is of course free to claim it, is that no authority could grant it to the more than seven billion people inhabiting this planet at this time. The fact that the MDGs make no mention of limits to growth implies a worldview that considers business as usual not as problematic but as extendable into the indefinite future. Only someone who believes that the Earth's resources are unlimited can regard their allocation as a universal right for an indefinitely large population; and only someone who believes that the world's population and its impact have not even come close to the Earth's carrying capacity will consider the goal of eradicating epidemics to be realistic. In addition to this fundamental flaw, the MDGs have been hampered by a lack of political commitment and consensus, and by the worldwide economic slowdown [35]. As Table 3 indicates, most of the MDGs are not being achieved by their target date of 2015. Instead they are to be replaced by a new set of goals, called Sustainable Development Goals (SDGs), to be formulated by September 2013 [36].

An explanation for this discrepancy between wishful thinking and practical failure must take into account the diversity of beliefs, values, and ideals-often summarised as ideologies-that inform people's notions of what constitutes progress [38]. Sometimes those notions create what Ronald Wright ([39], p. 8) referred to as 'progress traps'. Of particular importance are those beliefs that delimit the realm of the possible. An obvious example is cornucopianism, the belief that the growth of populations and economies is not subject to physical limits [40]. Under the cornucopian delusion, progress takes a very distinct shape of unending growth in human numbers, their consumption, and the quality of their lives. The absence of any scientific justification for this belief has relegated it to the realm of implicit yet powerful assumptions that still inform certain schools of academic thought such as neoclassical economics $[41,42]$.

Some of the listed programs for sustainable development seem indicative of cornucopianism. At least they do not explicitly acknowledge limits to growth or local overshoot, nor do they tend to take into account global environmental change resulting from the present situation of global overshoot. Many rely on economic growth (usually measured as GDP increase) as a means to raise income levels and provide trickle-down benefits from investment, the large-scale extraction of non-renewable resources to boost employment and trade balance, and converting from subsistence agriculture to staple industries for export. Those policies are supported by a trust in global trade relationships and an optimistic outlook on the potential of market forces, complemented by some regulation, to rectify global inequities and to eliminate poverty worldwide. The future is envisioned as a repetition of the past, only more of it. Raskin et al. [43] referred to this ideology as the Conventional Development Paradigm (CDP).

The well-publicised manifestations of the global environmental crisis (under the broad phenomena of climate change, pollution, resource scarcity, and the loss of biodiversity), as well as the abundant evidence for its anthropogenic causation, render the CDP a rather unrealistic kind of long term thinking. This is the kind of perspective that still moves people to welcome the discovery of new oil deposits as good news; without the denial of anthropogenic climate change such news would be received with ambivalence at best. It is also unrealistic because it assumes that the same institutions, regimes, and 
ways of thinking that undoubtedly contributed to the global environmental crisis are able to help us transcend it. This assumption can only be upheld if one denies or disregards the true extent of the crisis. It makes for an overly simplistic, laissez-faire type interpretation of sustainability that contradicts the bulk of the evidence reported by environmental scientists.

While those ideological deficiencies provide a plausible explanation for the failures of the MDGs and related development efforts, they do not explain their sporadic successes, and they offer little help towards finding ways out of the conundrum. Most of the development programs listed here derive their support partly from sources that are not as readily quantified as is bioproductivity-human ingenuity and spirit, social capital, and potential for learning. Also, ecological overshoot can proceed for quite some time without the loss of natural capital necessarily causing any immediate calamities [44]. Thus, development that is unsustainable can continue sometimes for generations before collapse becomes imminent. This undoubtedly contributes to the slowness of the collective learning process, as do a diverse assortment of counterproductive myths, cognitive biases, moral ineptitudes, and mental habits, all well characterised in the literature on what might be summarised as 'human nature' [38,45-48].

\section{A Utilitarian Theory of Development that Humanity Can Live With}

The contingencies of overshoot render it unlikely that the problems associated with underdevelopment can be effectively remedied by efforts that only focus on 'eliminating poverty' as the humanitarian ideal demands-regardless of how one defines poverty $[49,50]$. Two reasons conspire towards this obstacle: The first arises from the counterproductive effects of further global economic growth under overshoot; they necessitate that any growth in a poor country be accompanied by restraint in a rich country-a politically unlikely proposition.

The second reason lies in the futility of redistribution efforts; at this point in time, if a global dictatorship allocated exactly equal amounts of resources to every human being, we would still all starve, albeit rather slowly [25]. The fact that our current demand can only be sustainably met by about 1.5 planets means that even assuming perfect equity, at the current consumption level one third of humanity would be consuming part of the food producing 'machinery' itself [19]. People living in more extreme biogeographical regions and latitudes would be hardest pressed. Moreover, population growth would still proceed while food prices rise and fresh water and soils grow scarcer [51]. This means that the redistribution of resources cannot be the sole prescription for food security, even though it would certainly help alleviate some of the worst shortages.

In order to ensure lasting environmental security and acceptable survival [52] for all, humanity must reduce its total environmental impact before nature does this for us in very painful ways and before many more species are lost. This imposes a tragic inversion on the traditional humanitarian agenda of development. What is inverted here is nothing less than the holy grail of utilitarianism, often phrased as 'the greatest good for the greatest number'. Our collective environmental impact, described by the I = PAT relationship [53], clearly indicates a range of solution states encompassing numerous combinations of global population sizes and per capita affluence and technology use; all those solution states are sustainable and include population sizes below the current level (how far below depends partly on how long it will take us to get there). Furthermore, Potter's [52] hierarchy of survival modes suggests that some of those solutions are morally preferable to others (e.g. miserable survival for all at 5 billion vs. acceptable survival for all at 3 billion). Others (e.g. $[54,55,12])$ have come to similar conclusions. The holy grail of utilitarians now amounts to the minimum acceptable amount of good for the greatest sustainable number. This number is probably no more than about four billion people, and perhaps less than one billion [55-57].

What does this new inverted dictum mean for development aid? The need to reduce our numbers does not only arise from our excessive impact. The growing scarcity of key resources, particularly food and potable water, causes suffering that would be avoidable with a smaller population. Cohen $[54,55]$ framed the challenge of global food security in the analogy of a communal dinner table where some guests go hungry; in his words, the problem can be solved in three ways: (i) prepare a bigger dinner, (ii) put fewer forks on the table, (iii) teach better manners. Ehrlich and coworkers [58] reduced the challenge to a 'race between the stork and the plough'. Others (e.g. $[59,60])$ indicated that little, if any, room remains to increase food supply (i.e., speed up the plough, or make a bigger dinner), although adherents to the CDP (e.g. in [49]) would disagree. In effect, reducing the global population and changing our 'manners' are probably our only remaining options.

The link between the emancipation and education of women and decreases in reproductive rates seems well established cross-culturally. Several aid programs in our sample include educational components, and even in the MDGs this opportunity has been recognised under goal 3 (Table 3 ). Yet, as we pointed out earlier, the need for population reduction is rarely acknowledged explicitly. Family planning programs still face the opposition of powerful religious and cultural prejudices, spearheaded by collusive governments [12]. It is also clear that many manifestations of 
anthropogenic global environmental change proceed much too quickly at this stage for the documented reductions in fertility (or the much invoked demographic transitions to result from them) to effect any significant mitigation. This means that both environmental deterioration and population growth will proceed, albeit perhaps at reduced speeds, towards the inevitable collision point at which time much of international aid will need to take the form of disaster relief.

As for our 'manners', one aspect of development aid that could certainly benefit from revision is the lack of honesty associated with using the label of sustainable development. As we established earlier, development that is truly sustainable must fulfil the requirement of addressing the challenges of population, distributional inequities, and overshoot. In that sense, 'manners' include ethical standards and dominant belief systems that bar the way towards gains in efficiency, restraint in consumption, adaptation to inevitable changes, and conducive structural reforms. In all those directions, too, reformed education can make substantial contributions [38] and pave the way for a proliferation in 'positive deviance' in Parkin's [61] sense. While she applied her norms of 'sustainability-literate leadership' mainly to individuals and sociocultural communities, our conclusions suggest that they would be equally beneficial among the international community.

Such deviance is necessary because it seems clear that development initiatives that are primarily informed by the CDP can only help in the short term (as evident in GDP increases). In the longer term they will do more harm than good by reducing natural capital as evident in decreases of other statistics (e.g. the Inclusive Wealth Indicator, IWI) and increasing humanity's collective impact [62]. Rising GDP and shrinking IWI have been observed with some 'emerging economies' such as Brazil and India. Another case in point is the much acclaimed 'green revolution' that vastly boosted food production during the 1970s. In the short term it relieved shortages and prevented impending famines; in the long term, however, it will be regarded a disaster, as Hardin [11] predicted. The couple of decades of time that it bought us were not used wisely; instead, they were squandered on further growth under the belief that this revolution would never end. Now we are again facing famines-except that our numbers have doubled, our ecosystems are weaker, tens of thousands of species have disappeared, natural resources are further depleted, and global pollution has become worse. No other misadventure of conventional development policy illustrates the failings of the CDP better than this missed opportunity. Its humanitarian goals are rendered unattainable by its obsession with 'economic growth' as a human 'need'. In the light of our earlier conclusions such policies should not qualify as development proper. Not even
Sen's [2] more flexible principle of 'development as freedom' is able to accommodate ecological constraints or bring humanity closer to the new utilitarian ideal of minimum acceptable amount of good for the greatest sustainable number.

Utilitarian reinterpretations of development sometimes meet with objections based on human rights [63]. Rights become limited by a partial contradiction in the sense that insisting on some rights (i.e., rights that are not grantable) will create insecurity. In her critique of human rights theory Thomas [64] referred primarily to the enshrining of property rights under human rights law, which can, under conditions of limited resources, work at the expense of disenfranchised minorities. In the light of overshoot certain other human rights seem similarly counterproductive, such as the right to a 'clean environment', 'safe drinking water', or 'adequate nutrition'. Given a large enough global population (today's seven billion plus would qualify) and a single planet at our disposal, no world government could grant such privileges to all. One additional 'right' that has arguably proven not only ungrantable but outright harmful is the right to procreate at will [25].

This need for changing our notions about rights points to those challenges that are situated inside the human psyche. By labeling nature as the non-human 'other', an inanimate heap of 'resources' for the taking, consisting of marvellously useful little automatons just waiting to prove their utility to human endeavours, we ultimately set ourselves up for moral bankruptcy and ecological suicide. What emerges are not just the deeply problematic ramifications of the dominant anthropocentric environmental ethic behind such development schemes as the UN's Millennium Goals, but a thorough revision of what it means to be 'modern' and what constitutes 'progress'.

Besides the obvious need to change our notions about human security, about nature, and about modernity, another internal challenge that is evident from the foregoing is the need to change our value priorities with respect to each other. As ecologies simplify and economies falter, centralised governance and the rule of law will become more tenuous. Thus, global development in the true sense means not only that most of us need to re-learn how to run selfsufficient, resilient local communities. It also means that we exercise compassion for those whom the crisis will have displaced from their homes. On 10 January 2012 the Bulletin of the Atomic Scientist once more reset its Doomsday Clock closer to midnight, citing dangers of nuclear proliferation, climate change, and the failure of political leaders to change 'business as usual' and to "set the stage for global reductions" ([65, p. 3). The ranks of displaced multitudes are certain to swell once rising sea levels have inundated some of the world's heavily populated coastal lands [66]. In the absence of decisive initiative by the 
UNHCR that would impart on environmental refugees the status of 'world citizens' (or at the very least accord them full official refugee status) [67], their fate depends on the charity of other countries and on charitable NGOs-which, in the midst of shortages and economic downturns, cannot be taken for granted. Clearly the human conscience represents as important a 'tipping point' as do geophysiological variables. Many of these challenges have been reiterated at the Planet Under Pressure Conference (March 2012) leading up to Rio+20 [68].

Since sustainable development in the true sense must incorporate all of those changes it comes as no surprise that so little of it is in evidence. If the developed world's idealistic efforts at development aid were really motivated by the urge to increase justice, human security, and well-being globally while

\section{References}

1. Haslam PA, Schafer J, Beaudet, P. Introduction to International Development: Approaches, Actors and Issues. 2 ed. Oxford, UK: Oxford University Press; 2012.

2. Sen A. Development as Freedom. Oxford, UK: Oxford University Press; 1999.

3. UNDP. Human Development Report. New York, USA: United Nations; 2011. Available from: http://hdr.undp.org/en/reports/global/hdr2011 (accessed on 2 March 2013).

4. Hastings D. The Human Security Index: An Update and a New Release. Document Report Version 1.0 (March), 2011. Available from: http://www. humansecurityindex.org/wordpress/wp-content/ uploads/2012/02/hsiv2-documentation-report1_1.pdf (accessed on 2 March 2013).

5. Bartlett AA. 2012. The meaning of sustainability. Teachers Clearinghouse for Science and Society Education Newsletter. 2012; 31(1):1-14. http://www. populationmedia.org/2012/04/04/the-meaning-ofsustainability-by-professor-emeritus-albert-a-bartlett/ (8 August 2012).

6. International Union for the Conservation of Nature (IUCN). Caring for the Earth. A strategy for sustainable living. Gland, Switzerland: IUCN, UNEP, WWF; 1991.

7. Paris Declaration on Aid Effectiveness. 2005. Available from: http://www.oecd.org/dataoecd/11/41/ 34428351.pdf (accessed on 2 March 2013).

8. Alesina A, Dollar D. Who gives foreign aid to whom and why? Journal of Economic Growth. 2000; 5(1):33-63.

http://dash.harvard.edu/bitstream/handle/1/4553020/ alesina_whogives.pdf (accessed on 2 March 2013).

9. Office of the Special Envoy for Haiti. Key statistics. New York: United Nations; 2012. Available from: http://www. haitispecialenvoy.org/relief-andrecovery/key-statistics/ (accessed on 20 June 2012).

10. Singer P. Famine, affluence and morality. In achieving the global transition to a sustainable world, they would not hesitate to start at the top end and reduce the obscene levels of consumption evident there. In many respects that would be an easier undertaking than encouraging development at the lower end without also promoting net growth. Yet, even if we end up not making use of any of those opportunities we can be assured that sustainability will come our way eventually at the hands of mother nature.

\section{Acknowledgments}

This article is based in part on a paper presented at the 2nd World Sustainability Forum (2012) and a chapter by the authors in reference [25].

May L, Wong K, Delston J, editors. Applied Ethics: A Multicultural Process, 5th ed. Toronto, Canada: Prentice Hall; 2011. pp. 216-225.

11. Hardin G. Carrying capacity as an ethical concept. In May L, Wong K, Delston J, editors. Applied Ethics: A Multicultural Process, 5th ed. Toronto, Canada: Prentice Hall; 2011. pp. 186-194.

12. The US have for most of the past decades pursued a policy of refusing to fund any programs that include birth control measures of any kind in Third World countries. This amounted to cancelling all US development aid, as well as US participation in international aid, that was in any way associated with family planning. Ehrlich PR, Ehrlich $\mathrm{AH}$. One with Nineveh: Politics, consumption and the human future. Washington, DC, USA: Island Press; 2004.

13. At the 1994 International Conference on Population and Development in Cairo the goal of fertility reduction was dismissed in favour of women's empowerment. Instrumental in this outcome were the international women's movement, the US government, and the Holy See (McIntosh CA, Finkle JL. The Cairo Conference on Population and Development: A new paradigm? Population and Development Review. 1995;21(2):223-260. A reference to reproductive rights was deleted from the Rio+20 report.

14. Messner JJ. Failed states index 2011. Foreign Policy (July/August), Washington, DC, USA: The Fund for Peace \& The Carnegie Endowment for International Peace; 2011.

15. Chambers N, Simmons C, Wackernagel $M$. Sharing nature's interest: Ecological footprints as an indicator of sustainability. London, UK: Earthscan Publ. Ltd; 2000.

16. Rees WE. Ecological footprints and biocapacity: Essential elements in sustainability assessment. In: Dewulf J, Van Langenhove $\mathrm{H}$, editors. Renewables-Based Technology: Sustainability Assessment. Chichester, UK: John Wiley and Sons; 2006. pp. 143-158. 
17. Wackernagel M. Advancing sustainable resource management: Using ecological footprint analysis for problem formulation, policy development, and communication. DG Environment, European Commission; 2001. Available from: http://ec.europa. eu/environment/enveco/waste/pdf/wackernagel.pdf (accessed on 2 March 2013).

18. Lautensach SW, Lautensach AK. Prioritising the variables affecting human security in South-East Asia. Austrian Journal of South-East Asian Studies. 2010;3(2):194-210. Available from: http://www.seas.at/ wp-content/plugins/download-monitor/download.php? id $=40$ (accessed on 2 March 2013).

19. An alternative approach to determine whether a country has incurred an ecological deficit or a surplus involves subtracting the footprint from the biocapacity (Global Footprint Network. Living planet report 2012: Biodiversity, biocapacity, and better choices. Oakland, CA: GFN \& WWF; 2012. Available from: http://www.footprintnetwork.org/images/uploads/ LPR_2012.pdf (accessed on 2 March 2013). However, the resulting differences are less commensurable in terms of the development status of different countries than are quotients.

20. Ewing B, Moore D, Goldfinger S, Oursler A, Reed A, Wackernagel M. The ecological footprint atlas 2010. Oakland, CA: Global Footprint Network; 2010. Available from: http://www.footprintnetwork.org (accessed on 2 March 2013).

21. Moyo D. Dead aid: Why aid is not working and how there is another way for Africa. New York, NY, USA: Farrar, Straus and Giroux; 2009.

22. Organization for Economic Cooperation and Development (OECD). Aid Statistics, Statistics by Region 2013: Aid at a Glance. Paris: OECD; 2013. Available from: http://www.oecd.org/dac/stats/ regionalcharts (accessed on 16 January 2013).

23. Central Intelligence Agency (CIA). The World Factbook 2012. Washington, DC: CIA; 2012. Available from: https://www.cia.gov/library/publications/theworld-factbook/ (accessed on 2 March 2013).

24. Weisman A. The World Without Us. Toronto: Harper Collins; 2007.

25. Lautensach AK, Lautensach SW, editors. Human security in world affairs: Problems and opportunities. Vienna: Caesar Press; 2013.

26. Sorrell S, Speirs J, Bentley R, Brandt A, Miller $R$. An assessment of the evidence for a near-term peak in global oil production. London, UK: UK Energy Research Centre Report; 2009. Available from: http://www.ukerc.ac.uk/support/tiki-index.php?page= Global+Oil+Depletion (accessed on 9 August 2012).

27. Heinberg $R$, Lerch $D$. The post-carbon reader. Heraldsburg, CA: Watershed Media; 2010.

28. Rubin J. The end of growth. Toronto: Random House Canada; 2012.

29. WCED (World Commission on Environment and Development). Our Common Future: The Brundtland Report. Oxford, UK: Oxford University Press; 1987.
30. Keiner $M$, editor. The future of sustainability: An anthology. Zurich, Switzerland: Swiss Federal Institute of Technology \& Dordrecht, The Netherlands: Springer; 2006.

31. United Nations. Global trends and status of indicators of sustainable development. New York: UN Department of economic and social affairs; 2006. Available from: http://www.un.org/esa/sustdev/csd/ csd14/documents/bp2_2006.pdf (accessed on 16 January 2013; no longer active).

32. United Nations. End poverty 2015: Millennium development goals. New York: United Nations; 2009. Available from: http://www.un.org/millenniumgoals/ (accessed on 2 March 2013).

33. Initiatives of Change International and Cemus Research Forum. Land and life: Human security through sustainable development. Rio+20 Conference (14 June): UNCSD; 2012. Available from: http://www.uncsd2012.org/index.php?page=view\& type $=1000 \&$ nr $=213 \&$ menu $=126$ (accessed on 2 March 2013).

34. Annan K. In larger freedom: Towards development, security, and human rights for all. Executive Summary. New York, NY, USA: United Nations; 2005. Available from: http://www.un.org/ largerfreedom/executivesummary.pdf (accessed on 2 March 2013).

35. Millennium Development Goals Gap Task Force. MDG gap task force report: 2011 update. New York: United Nations; 2011. Available from: http:// www.un.org/en/development/desa/policy/mdg_gap $/ \mathrm{m}$ dg_gap2011/mdg8report2011_engw.pdf (accessed on 2 March 2013).

36. United Nations Development Program. Realising the future we want for all. New York, NY, USA: United Nations; 2012. Available from: http:// sustainabledevelopment.un.org/content/documents/ 6 14Post_2015_UNTTreport.pdf (accessed on 2 March 2013).

37. Bencko V, Quinn J. Health security for all? In Lautensach AK, Lautensach SW, editors. Human Security in World Affairs: Problems and Opportunities. Vienna, Austria: Caesarpress; 2013. pp. 321-351.

38. Lautensach AK. Environmental ethics for the future: Rethinking education to achieve sustainability. Saarbruecken, Germany: Lambert Academic Publ.; 2010.

39. Wright R. A short history of progress. Toronto, Canada: House of Anansi Press; 2004.

40. Ehrlich PR, Holdren J. The impact of population growth. Science. 1971;171(3977):1212-1217.

41. Hall CAS. Sanctioning resource depletion: Economic development and neoclassical economics. In Gibson WE, editor. Ecojustice - The Unfinished Journey. Buffalo, NY, USA: SUNY Press; 2004. pp. 201-212.

42. Daly $\mathrm{H}$. Ecological economics and sustainable development: Selected essays. New York, NY, USA: Edward Elgar; 2008. 
43. Raskin $P$, Banuri $T$, Gallopín $G$, Gutman $P_{r}$ Hammond A, Kates R, Swart R. Great transition: The promise and lure of the times ahead. Stockholm Environment Institute Polestar Report no. 10. Boston, MA, USA: SEI; 2002. Available from: http://www.seiinternational.org/publications?pid=1547 (accessed on 2 March 2013).

44. Raudsepp-Hearne $C$, Peterson $G$, Tengo $M$, Bennett EM, Holland T, Benessaiah K, MacDonald GK, Pfeifer L. Untangling the environmentalist's paradox: Why is human well-being increasing as ecosystem services degrade? BioScience. 2010;60:576-589.

45. Lilienfeld SO, Ammirati R, Landfield K. Giving debiasing away: Can psychological research on correcting cognitive errors promote human welfare? Perspective on Psychological Science. 2009;4(4):390398.

46. Gordon A, Suzuki D. It's a matter of survival. North Sydney, NSW, Australia: Allen \& Unwin Pty Ltd.; 1990.

47. Hodgkinson SP, Innes JP. The prediction of ecological and environmental belief systems: The differential contributions of social conservatism and beliefs about money. Journal of Environmental Psychology. 2000;32(3):285-294.

48. Rees WE. What's blocking sustainability: Human nature, cognition and denial. Sustainability: Science, Practice and Policy. 2010;6(2):13-25. Available from: http://sspp.proquest.com/archives/ vol6iss2/1001-012.rees.html (accessed on 20 January 2011).

49. Narrow definitions of poverty contribute to the inefficiency of this 'figh' against poverty. A common definition specifies earning less than the equivalent of two US dollars a day, and for 'absolute poverty' less than one dollar. Bindé J, Matsuura K, editors. Keys to the 21st century. Paris: UNESCO; 2001. p.359.

50. The implied universal assumption is that the ontologically objective condition of subminimal nutrition can be alleviated with the ontologically subjective medium of currency. Searle JR. The construction of social reality. New York, NY, USA: The Free Press; 1995.

51. Brown LE. Plan B: Rescuing a planet under stress and a civilization in trouble. Washington, DC, USA: Earth Policy Institute; 2003.

52. Potter VR. Global bioethics: Building on the Leopold legacy. East Lansing, MI, USA: Michigan State University Press; 1988.

53. Grossman R. The importance of human population to sustainability. Environment, Development, and Sustainability. 2012;14(3):1-5.

54. Cohen JE. How many people can the earth support? New York, NY, USA: W.W. Norton; 1995.

55. Cohen JE. Human population grows up. Scientific American. 2005;293(3):48-55.

56. Pimentel D, Pimentel M. Global environmental resources versus world population growth. Ecological Economics. 2006;59:195-198.

57. McCluney WR. Humanity's environmental future: Making sense in a troubled world. Cape Canaveral, Florida: SunPine Press; 2004. Available from: http://www.thefutureofhumanity.com (accessed on 2 March 2013).

58. Ehrlich PR, Ehrlich AH, Daily GC. The stork and the plow. New York, NY, USA: G.P. Putnam's Sons; 1995.

59. Cribb J. The coming famine: The global food crisis and what we can do to avoid it. Collingwood, Australia: CSIRO Publishing; 2010.

60. Roberts P. The end of food. New York, NY, USA: Houghton Mifflin Co.; 2008.

61. Parkin S. The positive deviant: Sustainability leadership in a perverse world. London, UK: Earthscan; 2010.

62. IHDP (International Human Dimensions Programme on Global Environmental Change). Inclusive wealth report 2012: Measuring progress towards sustainability. New York, NY, USA: IHDP \& UNEP; 2012. Available from: http://www.ihdp.unu.edu/ article/iwr (accessed on 2 March 2013).

63. UNDP (UN Development Programme). Human rights and the Millennium Development Goals: Making the link. New York. NY, USA: United Nations; 2007. Available from: http://www.hurilink.org/Primer-HRMDGs.pdf (accessed on 2 March 2013).

64. Thomas C. Global governance, development and human security: exploring the links. Third World Quarterly. 2001;22(2):159-75.

65. Bulletin of the Atomic Scientists (BAS). Doomsday Clock moves 1 minute closer to midnight. BAS: Washington, DC, 10 January 2012. Available from: http://www.thebulletin.org/content/media-center/ announcements/2012/01/10/doomsday-clock-moves1-minute-closer-to-midnight (accessed on 2 March 2013).

66. McKibben B. Eaarth: Making a life on a tough new planet. New York, NY, USA: Times Books; 2010.

67. Pearce F. Search for climate refugees. New Scientist. 2011;(30 April):6-7.

68. Brito L, Smith MS. State of the planet declaration. Report from the Planet Under Pressure Conference, 26-29 March 2012, London, UK; 2012. Available from: http://www.planetunderpressure2012. net/pdf/state_of_planet_declaration.pdf (accessed on 2 March 2013). 